\title{
Asymmetric Synthesis of Second-Generation Light-Driven Molecular Motors
}

\author{
Thomas van Leeuwen, Wojciech Danowski, Edwin Otten, ${ }^{\circledR}$ Sander J. Wezenberg, ${ }^{(0}$ and Ben L. Feringa*(1) \\ Stratingh Institute for Chemistry, University of Groningen, Nijenborgh 4, 9747 Groningen, AG, The Netherlands
}

Supporting Information

ABSTRACT: The enantiomeric homogeneity of light-driven molecular motors based on overcrowded alkenes is crucial in their application as either unidirectional rotors or as chiral multistate switches. It was challenging to obtain these compounds as single enantiomers via the established synthetic procedures due to loss of optical purity in the key step, i.e., the Barton-Kellogg olefination reaction. Searching for strategies to avoid racemization, a new class of light-driven molecular motors was designed, synthesized, and studied. The stereochemical integrity was fully preserved throughout the synthesis, and on the basis of photochemical and kinetic studies using $\mathrm{UV} /$ vis, $\mathrm{CD}$, and ${ }^{1} \mathrm{H}$ NMR spectroscopy, it was established that they still function properly as unidirectional molecular motors.

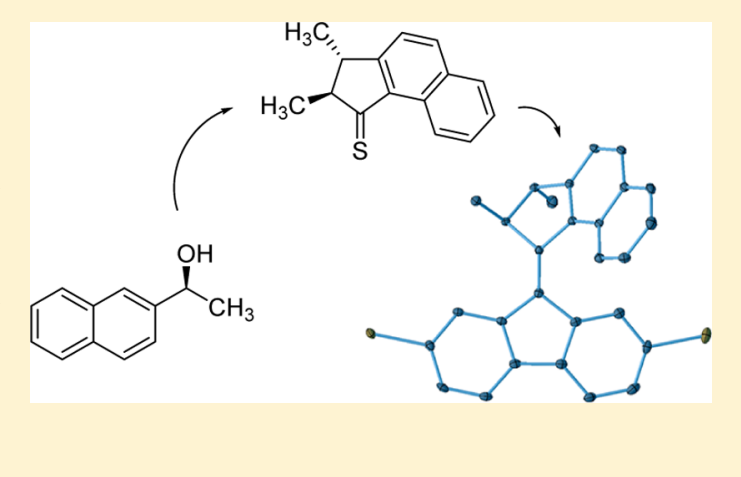

\section{INTRODUCTION}

The development of molecular motors and switches holds great promise for the field of molecular machinery. ${ }^{1}$ Continuous research efforts in the last three decades culminated in the development of a great variety of molecular machines able to perform functions at the nanoscale. ${ }^{2}$ In 1999, the first lightdriven unidirectional molecular motor based on overcrowded alkenes was developed by our group. ${ }^{3}$ These systems, which use light as fuel to accomplish unidirectional $360^{\circ}$ rotation around an axle involving a four-step mechanism, are among the most promising classes of molecular motors and switches to be applied in molecular nanotechnology (Scheme 1).

Focusing on the individual steps of the rotary cycle, a photochemical $E-Z$ isomerization transforms the thermodynamically favored isomer, for example, $(P)-(R)$-1 (Scheme 1), into a metastable isomer, that is $(M)-(R)-\mathbf{1}$. Subsequently, this photogenerated isomer undergoes a conformational change, usually referred to as the thermal helix inversion (THI), where the naphthalene moiety slips over the fluorenyl stator in order to reform the original isomer. The result of the energetically uphill photoisomerization and thermodynamically downhill THI is a $180^{\circ}$ counterclockwise rotation of the upper half relative to the lower half. Another photochemical step followed by a THI completes the unidirectional $360^{\circ}$ rotation around the double bond. Continuous irradiation at high enough temperature to allow THI then leads to repetitive unidirectional rotation. These molecular motors have been used for dynamic control of function. ${ }^{4}$ In the applications of these systems their enantiopurity is paramount. The configuration at the stereogenic center dictates the direction of rotation; hence, a collection of molecular motors rotates only in the same direction if the sample is enantiomerically pure. In our efforts to construct molecular machines and smart materials based on
Scheme 1. Four-Step Operating Mechanism Leading to Unidirectional Rotation of the Rotor (Red Upper Half) Relative to the Stator (Black Lower Half) Powered by Light (Depicted for the $R$ Enantiomer)

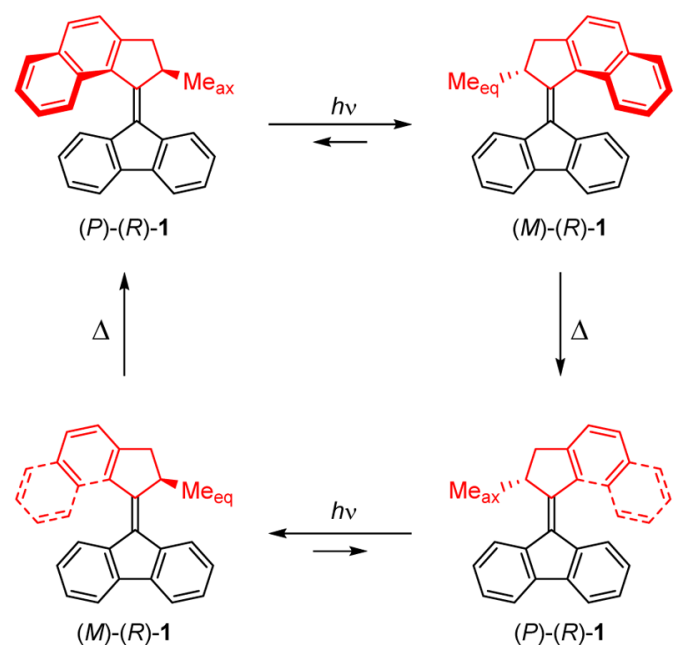

rotary molecular motors, access to enantiopure functionalizable compounds is often a necessity. We recently developed a method for the asymmetric synthesis of first-generation molecular motors using a gold-catalyzed enantioselective protonation and an ee-enhancing McMurry coupling. ${ }^{5}$ The enantioselective synthesis of second-generation molecular motors, however, was found to be more challenging. The Barton-Kellogg (BK) reaction is normally used to construct

Received: April 11, 2017

Published: May 1, 2017 


\section{Scheme 2. Synthetic Strategy toward Enantiopure Molecular Motors}
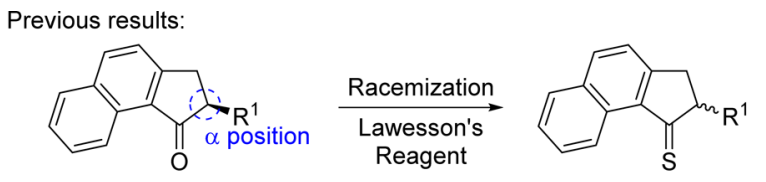

This work:
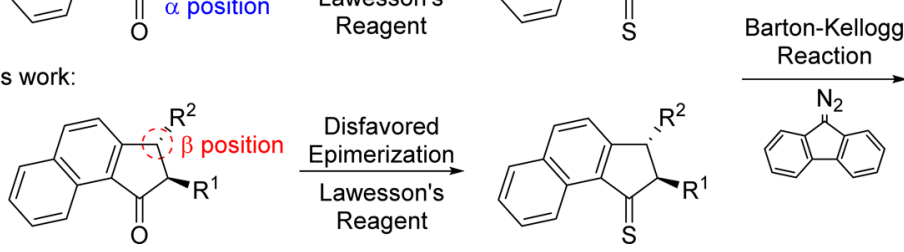

Racemic Product

Enantiopure Product

the sterically hindered double bond (the rotary axle), but it was found that the transformation of the precursor ketone into either thioketone or hydrazone (followed by the oxidation to the corresponding diazo compound) is accompanied by racemization of the stereogenic $\alpha$ center, resulting in racemic product, when starting from enantiopure ketones (Scheme 2). ${ }^{6}$

In 2010, a method was developed to reduce the loss of optical purity during the formation of the hydrazone and diazo precursor. ${ }^{6}$ Using bis-TBS hydrazine, $\mathrm{Sc}(\mathrm{OTf})_{3}$, and short reaction times, the racemization during hydrazone formation could be suppressed to some extent (starting with $98 \%$ ee, product with $86 \%$ ee is obtained). Alternatively, the groups of Lautens $^{7-9}$ and Tietze ${ }^{10-15}$ developed elegant palladiumcatalyzed cascade reactions to access sterically hindered tetrasubstituted alkenes, but many structural motifs commonly found in molecular motors are still unattainable with these methods. Considering the importance of ready access to optically active molecular motors, we explored new ways to synthesize these compounds without having to rely on chiral HPLC separations. It was reasoned from previous experience that the racemization of either chiral hydrazone or thione was difficult to avoid. Therefore, it was opted to structurally modify the molecular motor in such a way that racemization (or epimerization) of the $\alpha$ stereocenter during the synthesis is disfavored. In the design of a new class of molecular motors there are generally two considerations: (i) the modification should not impair the proper functioning of the molecular motor and (ii) the modified motor should contain an $\alpha$ stereocenter. Previously, molecular motors were studied in which the stereocenter was moved from the $\alpha$ position to the $\beta$ position, and although this change seems to be a good option to avoid racemization of the stereocenter, it was found that these resulting molecular rotors are not fully unidirectional. ${ }^{16}$ It was reasoned that the introduction of an additional substituent at the $\beta$ position with trans vicinal stereochemistry, while maintaining the $\alpha$ substituent, would disfavor epimerization during thioketone formation due to increased steric hindrance caused by the cis configuration of the $\alpha$ and $\beta$ substituent, upon epimerization. Here, we show that the addition of a $\beta$ substituent allows for the facile enantioselective synthesis of molecular motors based on overcrowded alkenes, and that this modification does not impair proper functioning of these motors.

\section{RESULTS AND DISCUSSION}

Density functional theory (DFT) (B3LYP 6/31G(d,p)) was used to predict the behavior of known molecular motor 1 and motors $\mathbf{2 - 4}$, which were considered as potential synthetic targets (Table 1).
Table 1. Calculated Gibbs Free Energies (DFT B3LYP (6$31 \mathrm{G}(\mathrm{d}, \mathrm{p}))$ for Motors 1-4

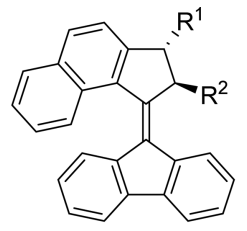

$$
\begin{array}{ll}
\text { 1: } R^{1}=H ; R^{2}=C_{3} & \text { 3: } R^{1}=C_{3} ; R^{2}=i-P r \\
\text { 2: } R^{1}=C_{3} ; R^{2}=\mathrm{CH}_{3} & \text { 4: } R^{1}=C_{3} ; R^{2}=H
\end{array}
$$

$\begin{array}{crrr}\text { compd } & \Delta^{\ddagger} G_{\mathrm{THI}}{ }^{a} & \Delta^{\ddagger} G_{-\mathrm{THI}}{ }^{a} & \Delta \Delta G^{a, b} \\ \mathbf{1} & 88.5 & 102.1 & 13.5 \\ \mathbf{2} & 90.0 & 101.8 & 11.8 \\ \mathbf{3} & 87.4 & 97.8 & 10.4 \\ \mathbf{4} & 103.8 & 105.9 & 2.1\end{array}$

${ }^{a} \mathrm{~kJ} / \mathrm{mol} .{ }^{b} \Delta \Delta G$ between the metastable and the stable state.

It was found previously that the behavior of molecular motors could be accurately predicted using this method. ${ }^{17}$ For each motor, the stable, metastable, and transition state (TS) for the THI were found by a potential energy scan (PES) using the semiempirical PM6 followed by a reoptimization with DFT. An energy diagram for $\mathbf{2}$ is given in Figure 1, and the calculated Gibbs free energies for the geometry-optimized structures for motors $\mathbf{1 - 4}$ are given in Table 1 .

The free energy differences characterize the behavior of the motor. The $\Delta^{\ddagger} G_{\mathrm{THI}}$ is related to the speed of rotation in the forward direction, while $\Delta^{\ddagger} G_{-\mathrm{THI}}$ determines the speed of rotation in the backward direction. If the Gibbs free energy difference between the stable and metastable form is large

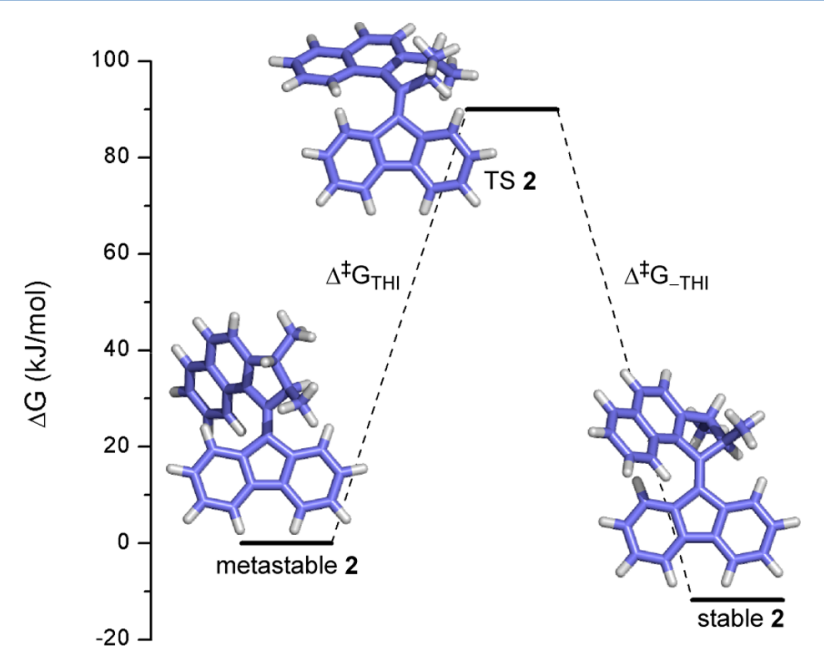

Figure 1. Energy diagram for the THI of 2. 
Scheme 3. Synthesis of Ketone $9^{18}$

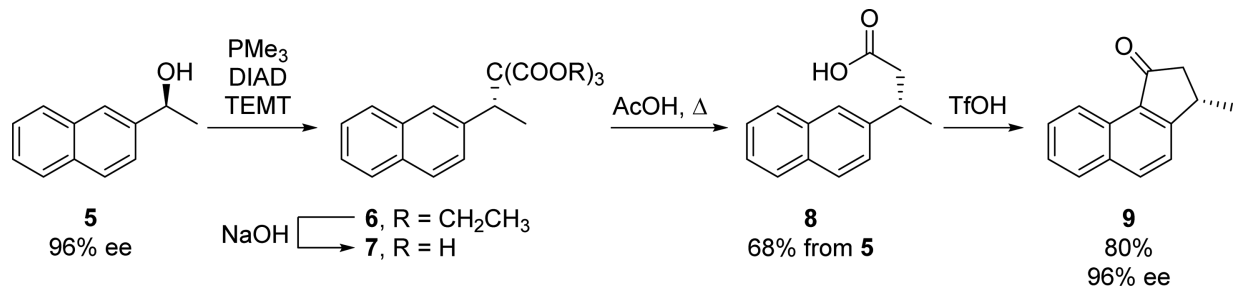

Scheme 4. Synthesis of Motors 2 and 3

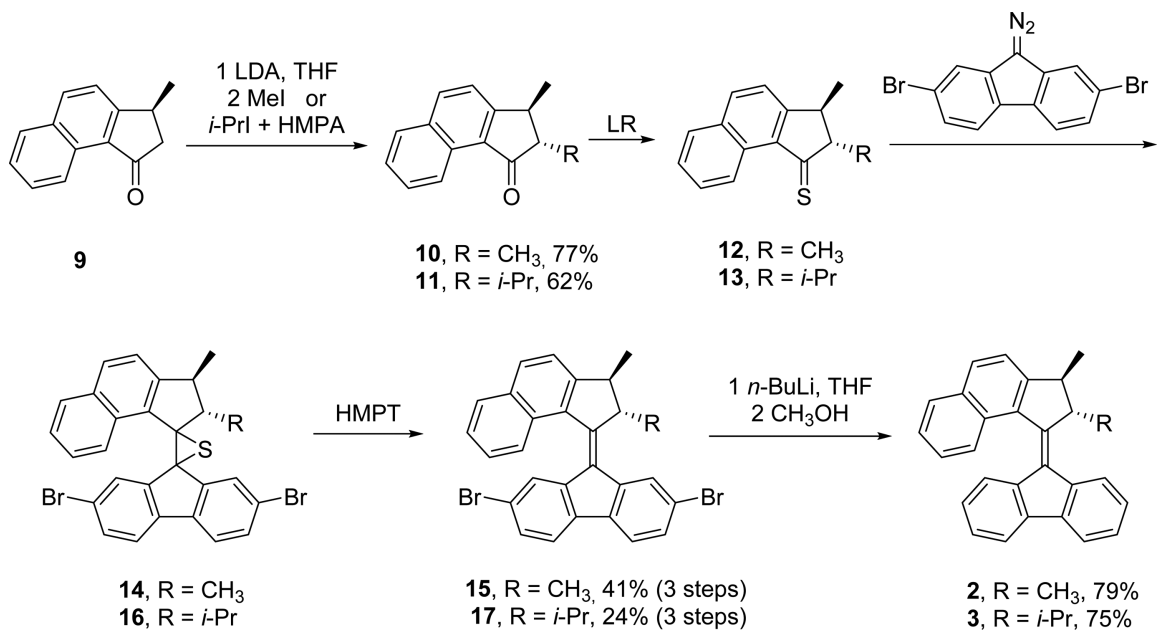

$(\Delta \Delta G>10 \mathrm{~kJ} / \mathrm{mol})$, as is the case for motors $1-3$, the THI in the forward direction is much faster, leading to unidirectional rotation. However, if the difference in stability between the stable and metastable isomer becomes small, as for motor 4, the rate of the THI in the forward and backward reaction become comparable, with the consequence that the motor is not fully unidirectional in its rotation. This behavior has previously been observed for motors which lack an $\alpha$ substituent. ${ }^{16}$ These calculations suggest that motor $\mathbf{2}$ and $\mathbf{3}$ would both function as unidirectional motors with comparable speed as the reported known motor 1. On the basis of these calculations, it is anticipated that the introduction of a $\beta$ substituent does not compromise the motor function, while it can avoid the loss of optical purity during the $\mathrm{BK}$ reaction.

The synthesis started with the commercially available alcohol 5 (96\% ee) (Scheme 3). The alcohol was converted following a literature procedure ${ }^{18}$ into tris ester 6 employing a Mitsunobu reaction using triethylmethanetricarboxylate (TEMT) as nucleophile, with inversion of stereochemistry. ${ }^{18}$ After saponification of 6 , the tris acid 7 was obtained, which was decarboxylated to afford acid $\mathbf{8}$ after purification by column chromatography (68\% yield in three steps). Cyclization of acid 8 with TfOH afforded the corresponding ketone 9 in $96 \%$ ee, as determined by chiral SFC. Deprotonation of ketone 9 with LDA followed by the addition of either MeI or HMPA and $i$-PrI afforded ketones $\mathbf{1 0}$ and 11, respectively (Scheme 4).

Ketone $\mathbf{1 0}$ was obtained as a mixture of isomers (trans/cis 9:1) that could be separated after conversion to the thioketone stage (compound 12) The thioketones 12 and 13 were prepared by the action of Lawesson's reagent (LR) and were coupled to 2,7-dibromodiazofluorene by stirring in THF at rt, affording a mixture of episulfide and the desired overcrowded alkene. 2,7-Dibromodiazofluorene was used instead of the unsubstituted diazofluorene for several reasons. First, unsub- stituted diazofluorene readily dimerizes into bifluorenylidene, a compound which is difficult to separate from the desired product, and the introduction of bromine substituents suppresses this dimerization. Second, the bromo groups increase the crystallinity, allowing for facile recrystallization of the desired products. Finally, the bromine groups form nice handles for the introduction of functional groups in order to synthesize functional molecular motors. The mixture of alkene and episulfide, obtained after the BK reaction, was treated with hexamethylphosphorous triamine (HMPT) in THF to fully convert the episulfide into the corresponding alkene to afford 15 (96\% ee) and 17 (96\% ee). The ee of the starting alcohol $\mathbf{5}$ was $96 \%$ ee; thus, no loss in optical purity was detected during the synthesis of $\mathbf{1 5}$ and 17. Furthermore, motors 15 and 17 were obtained enantiomerically pure $(\geq 99 \%$ ee $)$ after recrystallization from heptane. For the synthesis of the parent motors 2 and 3, the bromine substituents were removed by halogen-lithium exchange with $n$-BuLi followed by quenching with $\mathrm{CH}_{3} \mathrm{OH}$. X-ray crystallography was performed on 15 to confirm the absolute configuration $((M)-(S, S)-15)$ and relative stereochemistry. The two stereogenic methyl groups are positioned trans to each other, and $M$ helicity is observed with an $S$ absolute configuration at the $\alpha$ stereocenter (Figure 2 and Figure S41).

With the products 2 and $\mathbf{3}$ in hand, the photochemical and subsequent thermal isomerization steps were studied. Irradiation of a solution of 2 in $\mathrm{CH}_{2} \mathrm{Cl}_{2}$ resulted in a red-shifted absorption spectrum, and clear isosbestic points were detected, indicative of the isomerization of the stable to the metastable form (Figure 3a).

$\mathrm{UV} / \mathrm{vis}$ spectroscopy indicated that the metastable state thermally relaxes to the stable state, and the reaction rate of this process was followed at six temperatures $\left(15-27.5{ }^{\circ} \mathrm{C}\right)$. Eyring analysis gave a $\Delta^{\ddagger} G\left(20^{\circ} \mathrm{C}\right)$ of $88.8 \pm 1 \mathrm{~kJ} / \mathrm{mol}$ for the THI of 


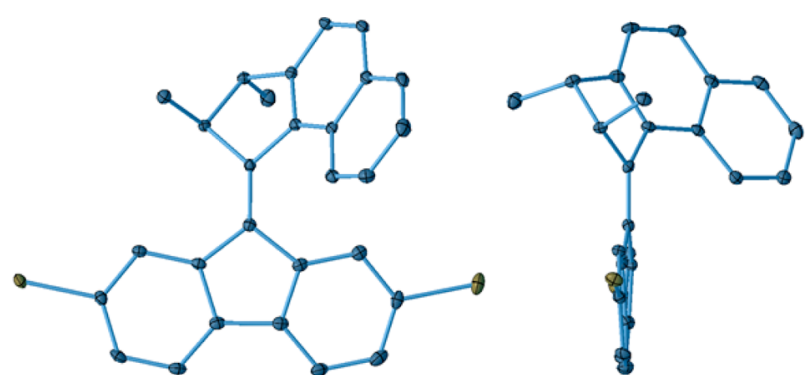

Figure 2. X-ray structure of $(M)-(S, S)-15$. Ellipsoids set at $50 \%$ probability. Hydrogen atoms are omitted for clarity. (Left) Front view. (Right) Side view.

2 (Figure S39), in close agreement with the DFT-predicted value of $\Delta^{\ddagger} G_{\text {calc }}\left(20{ }^{\circ} \mathrm{C}\right)=90.0 \mathrm{~kJ} / \mathrm{mol}$. The same experiments were performed for 3 , and similar behavior was observed upon irradiation (Figure S24). Eyring analysis of the THI afforded a $\Delta^{\ddagger} G\left(20^{\circ} \mathrm{C}\right)$ of $83.9 \pm 1 \mathrm{~kJ} / \mathrm{mol}$ (Figure S40), which is also in agreement with the DFT-predicted value $\left(\Delta^{\ddagger} G_{\text {calc }}\left(20^{\circ} \mathrm{C}\right)=\right.$ $87.4 \mathrm{~kJ} / \mathrm{mol})$. In the $\mathrm{CD}$ absorption spectrum, the $M$ helicity of $(S, S)-2$ gave rise to a positive Cotton effect. The sign of the CD absorption inverts upon irradiation, consistent with the formation of the metastable $(P)-(S, S)-\mathbf{2}$ isomer (Figure $3 \mathrm{~b}$ ). The photochemical and thermal behavior of 2 was further investigated via ${ }^{1} \mathrm{H}$ NMR spectroscopy. A solution of $\mathbf{2}$ in $\mathrm{CD}_{2} \mathrm{Cl}_{2}$ was irradiated with $365 \mathrm{~nm}$ light at $-40{ }^{\circ} \mathrm{C}$. Upon photoinduced conversion from the stable to the metastable form, the methyl groups, initially positioned in the pseudo axial conformation, adopt pseudoequatorial positions. This conformational change is apparent in the changes in the ${ }^{1} \mathrm{H}$ NMR spectra, where $\mathrm{H}_{\mathrm{a}}$ and $\mathrm{H}_{\mathrm{b}}$ shift from 1.29 and 1.35 ppm to 1.49 and $1.57 \mathrm{ppm}$, respectively, as well as the concomitant shifts of protons $\mathrm{H}_{\mathrm{c}}$ and $\mathrm{H}_{\mathrm{d}}$ (Figure 4 and Figure S19).

The photostationary state (PSS) ratio at $365 \mathrm{~nm}$ was $81 / 19$ (metastable:stable) by integration of the signals. Heating the sample to $30{ }^{\circ} \mathrm{C}$ leads to full conversion to the stable isomer (Figure S20). It must be noted that the thermal relaxation can, in principle, proceed via two pathways, i.e., the anticipated "forward" THI or a "backward" thermal $E-Z$ isomerization (TEZI). Since the TEZI energy barrier is usually much higher, ${ }^{17}$ and considering the good correlation between the calculated barrier for the THI and experimentally found $\Delta^{\ddagger} G$, it is most likely that the metastable isomer relaxes via the THI pathway. Nevertheless, to unequivocally prove that the introduction of a $\beta$ substituent does not affect the unidirectionality of the rotary motion of this type motor, the TEZI pathway was excluded by experiment. To this end, a derivative of $\mathbf{2}$ was synthesized with a methoxy moiety in the lower half. Irradiation of stable $(Z)-\mathbf{1 8}$ in $\mathrm{CD}_{2} \mathrm{Cl}_{2}$ afforded a PSS mixture of 80:20 (metastable (E)-18/stable (Z)-18). (Figure S21). Heating the sample to $30{ }^{\circ} \mathrm{C}$ led to the full conversion of metastable $(E)-\mathbf{1 8}$ to stable $(E)-\mathbf{1 8}$ as shown by NMR analysis (Figure S22), thereby excluding any possible TEZI reaction (Scheme 5), since via the latter pathway the initial ( $Z$ )-18 would have been reformed.

\section{CONCLUSIONS}

Light-driven unidirectional molecular motors based on overcrowded alkenes are an important class of molecular motors holding great promise for their application in molecular machinery. The enantiopurity of these compounds is crucial in their application. Previously, it was found challenging to obtain enantiopure molecular motors, due to racemization of the $\alpha$ stereocenter of the chiral ketones used in the BK olefination reaction. To bypass this loss in optical purity, a new class of motors has been designed with an additional group in the $\beta$ position. It was found that the introduction of a methyl group at the $\beta$ position disfavors the epimerization of the $\alpha$ stereogenic center during the formation of the thioketone and the $\mathrm{BK}$ reaction, thereby allowing for their facile enantioselective synthesis. UV/vis, CD, and ${ }^{1} \mathrm{H}$ NMR spectroscopy studies revealed that the introduction of this extra methyl group at the $\beta$ position does not compromise the unidirectional rotation of the molecular motor. This strategy greatly improved accessibility to single enantiomers of second-generation molecular motors and facilitates the development of applications based on this class of rotary molecular motors.

\section{EXPERIMENTAL SECTION}

General Remarks. All reagents were obtained from commercial sources and used as received without further purification. (S)-1(Naphthalen-2-yl)ethan-1-ol was obtained from Sigma-Aldrich. Dry solvents were obtained from a MBraun solvent purification system. Column chromatography was performed on a Reveleris X2 flash chromatography system. TLC: silica gel 60 , Merck, $0.25 \mathrm{~mm}$. HRMS were recorded on an LTQ Orbitrap XL. NMR spectra were obtained using a Varian Mercury Plus $\left({ }^{1} \mathrm{H}: 400 \mathrm{MHz},{ }^{13} \mathrm{C}: 100 \mathrm{MHz}\right.$ ) or a Varian Innova $\left({ }^{1} \mathrm{H}: 500 \mathrm{MHz}\right)$ instrument in $\mathrm{CDCl}_{3}$, or $\mathrm{CD}_{2} \mathrm{Cl}_{2}$.
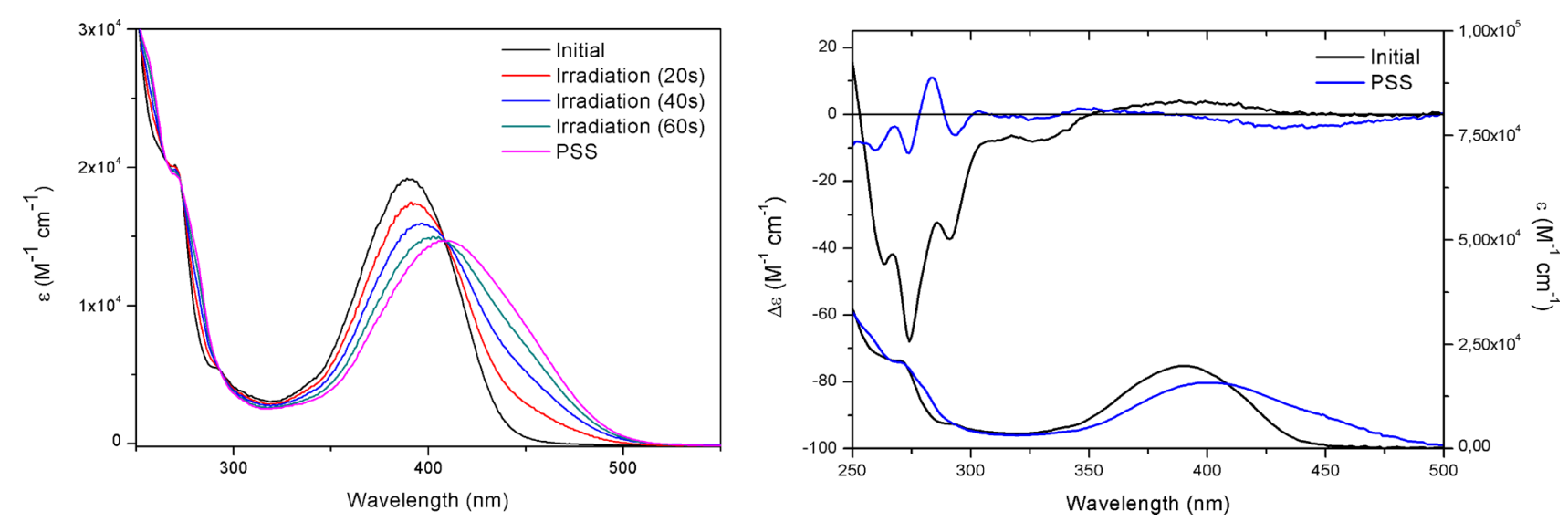

Figure 3. (a) Changes in UV/vis spectrum of a solution of 2 in $\mathrm{CH}_{2} \mathrm{Cl}_{2}$ upon irradiation at $365 \mathrm{~nm}$. (b) Changes in $\mathrm{CD}$ spectrum of a solution of 2 in $\mathrm{CH}_{2} \mathrm{Cl}_{2}$ upon irradiation at $365 \mathrm{~nm}$. 


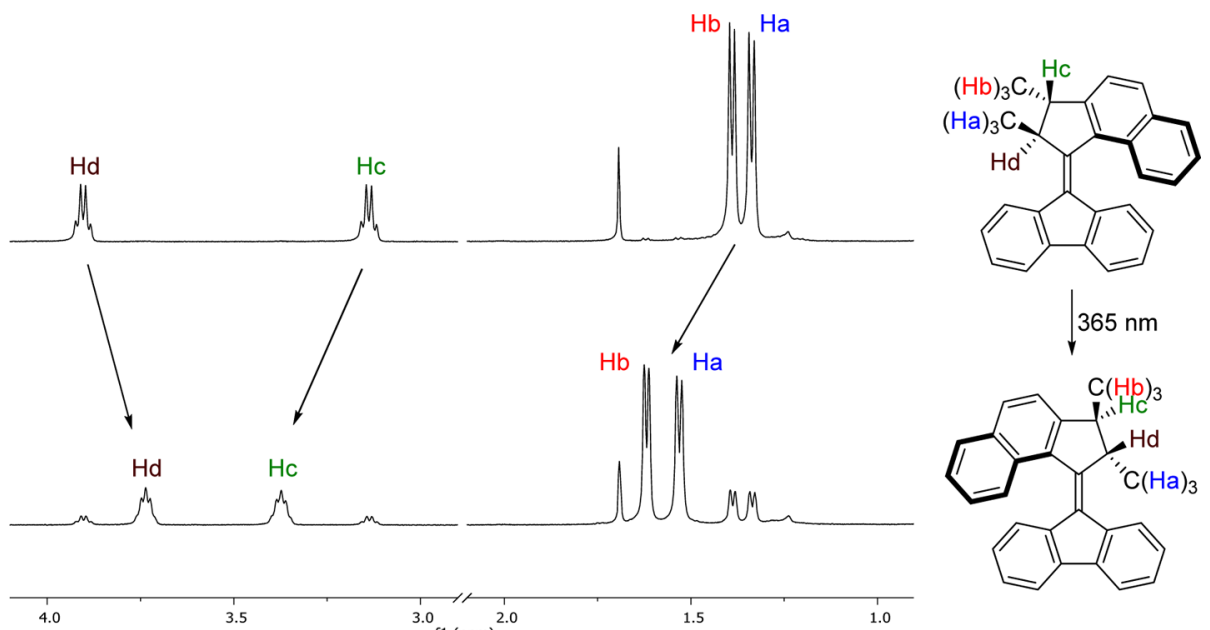

Figure 4. Changes in the ${ }^{1} \mathrm{H}$ NMR spectrum of a solution of 2 in $\mathrm{CD}_{2} \mathrm{Cl}_{2}$ upon irradiation at $365 \mathrm{~nm}$ at $-40{ }^{\circ} \mathrm{C}$.

Scheme 5. Photochemical and Thermal Isomerization Behavior of 18
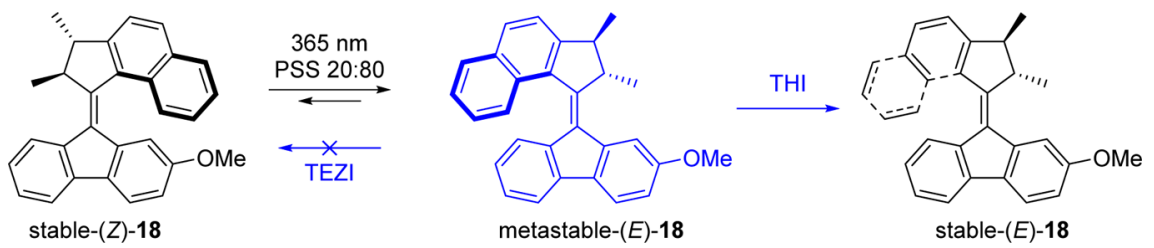

Chemical shifts are reported in $\delta$ units $(\mathrm{ppm})$ relative to the residual solvent signal of $\mathrm{CDCl}_{3}\left({ }^{1} \mathrm{H}\right.$ NMR, $\delta 7.26 \mathrm{ppm} ;{ }^{13} \mathrm{C} \mathrm{NMR}, \delta 77.0$ ppm) or $\mathrm{CD}_{2} \mathrm{Cl}_{2}\left({ }^{1} \mathrm{H} \mathrm{NMR}, \delta 5.32 \mathrm{ppm}\right)$. For ${ }^{1} \mathrm{H}$ NMR spectroscopy, the splitting pattern of peaks is designated as follows: $\mathrm{s}$ (singlet), $\mathrm{d}$ (doublet), $\mathrm{t}$ (triplet), (multiplet), br (broad), p (quintet), or $\mathrm{dd}$ (doublet of doublets). UV-vis absorption spectra were measured on a Hewlett-Packard 8453 diode array spectrometer in a $1 \mathrm{~cm}$ quartz cuvette. Dichloromethane used for spectroscopic studies was of spectroscopic grade (UVASOL, Merck). CD spectroscopy was performed on a JASCO J-810 spectropolarimeter. Enantiomeric ratios were determined by HPLC analysis using a Shimadzu LC-10ADVP HPLC equipped with a Shimadzu SPD-M10AVP diode array detector. Supercritical fluid chromatography (SFC) analysis was performed on a Thar Technologies, Inc. (Waters) Investigator II system. Irradiation experiments were performed using Thorlab LEDs (M365F1). Density functional theory (DFT) calculations were carried out with the Gaussian 09 program (rev. D.01) program package. ${ }^{19}$ All of the calculations were performed on systems in the gas phase using the Becke's three-parameter hybrid functional ${ }^{20}$ with the LYP correlation functional $^{21,22}$ (DFT B3LYP/6-31G(d,p)). Each geometry optimization was followed by a vibrational analysis to determine that a minimum or saddle point on the potential energy surface was found.

Synthetic Procedures. (S)-3-(Naphthalen-2-yl)butanoic Acid (8). Trimethylphosphine $(1 \mathrm{M}$ in toluene, $11.6 \mathrm{~mL}, 11.6 \mathrm{mmol})$ and diisopropyl azodicarboxylate were added dropwise $(2.35 \mathrm{~g}, 11.61$ $\mathrm{mmol}$ ) to a solution of (S)-1-(naphthalen-2-yl)ethan-1-ol (1.00 g, 5.81 $\mathrm{mmol})$ and triethyl methanetricarboxylate $(2.70 \mathrm{~g}, 11.61 \mathrm{mmol})$ in toluene $(10 \mathrm{~mL})$ at $0{ }^{\circ} \mathrm{C}$, and the mixture was subsequently stirred for $16 \mathrm{~h}$ at rt. EtOAc $(20 \mathrm{~mL})$ was added, and the organic layer was washed with water $(40 \mathrm{~mL})$, an aqueous solution of $\mathrm{HCl}(1 \mathrm{M}, 40$ $\mathrm{mL})$, and brine $(40 \mathrm{~mL})$, dried over $\mathrm{Na}_{2} \mathrm{SO}_{4}$, and concentrated in vacuo. The obtained product was dissolved in $\mathrm{EtOH}(10 \mathrm{~mL})$, and an aqueous solution of $\mathrm{NaOH}(3 \mathrm{M}, 3 \mathrm{~mL})$ was added. The reaction mixture was heated at reflux for $16 \mathrm{~h}$ and subsequently concentrated in vacuo. EtOAc $(20 \mathrm{~mL})$ was added to the crude product followed by an aqueous solution of $\mathrm{HCl}(2 \mathrm{M}, 20 \mathrm{~mL})$. The organic layer was washed with brine, dried over $\mathrm{Na}_{2} \mathrm{SO}_{4}$, and reduced in vacuo. The crude product was dissolved in acetic acid, heated at reflux for $16 \mathrm{~h}$, reduced in vacuo, and purified by column chromatography $\left(\mathrm{SiO}_{2}\right.$, pentane/
EtOAc) to afford 8 as a white solid ( $846 \mathrm{mg}, 3.95 \mathrm{mmol}, 68 \%): \mathrm{mp}$ $65-68{ }^{\circ} \mathrm{C}$; ${ }^{1} \mathrm{H}$ NMR $\left(400 \mathrm{MHz}, \mathrm{CDCl}_{3}\right) \delta 11.23(\mathrm{br}, 1 \mathrm{H}), 7.93-7.79$ $(\mathrm{m}, 3 \mathrm{H}), 7.79-7.64(\mathrm{~m}, 1 \mathrm{H}), 7.61-7.45(\mathrm{~m}, 2 \mathrm{H}), 7.42(\mathrm{dd}, J=8.5$, $1.8 \mathrm{~Hz}, 1 \mathrm{H}), 3.50(\mathrm{~h}, J=7.1 \mathrm{~Hz}, 1 \mathrm{H}), 2.86-2.67(\mathrm{~m}, 2 \mathrm{H}), 1.45(\mathrm{~d}, J=$ $7.0 \mathrm{~Hz}, 3 \mathrm{H}) ;{ }^{13} \mathrm{C}$ NMR $\left(100 \mathrm{MHz}, \mathrm{CDCl}_{3}\right) \delta 178.9,142.8,133.5$, $132.3,128.2,127.6,127.6,126.0,125.4,125.3,124.9,42.5,36.2,21.8$; HRMS (ESI-) calcd for $\mathrm{C}_{14} \mathrm{H}_{13} \mathrm{O}_{2}[\mathrm{M}-\mathrm{H}]^{-}$231.0910, found 231.0923.

(S)-3-Methyl-2,3-dihydro-1H-cyclopenta[a]naphthalen-1-one (9). $\mathrm{TfOH}(5 \mathrm{~mL})$ was added to a solution of acid $8(800 \mathrm{mg}, 3.73 \mathrm{mmol})$ in $\mathrm{CH}_{2} \mathrm{Cl}_{2}(5 \mathrm{~mL})$ at $0{ }^{\circ} \mathrm{C}$. The reaction mixture was stirred for $0.5 \mathrm{~h}$ at $0{ }^{\circ} \mathrm{C}$ and subsequently quenched by the addition of ice. EtOAc (25 $\mathrm{mL}$ ) was added, and the organic layer was washed with a saturated solution of $\mathrm{NaHCO}_{3}(\mathrm{aq})(2 \times 30 \mathrm{~mL})$ and brine $(30 \mathrm{~mL})$, dried over $\mathrm{Na}_{2} \mathrm{SO}_{4}$, and concentrated in vacuo. The crude product was purified by column chromatography to afford 9 as a white solid (583 $\mathrm{mg}, 2.98$ mmol, 80\%): $\mathrm{mp} 76-79^{\circ} \mathrm{C}^{1}{ }^{1} \mathrm{H} \mathrm{NMR}\left(400 \mathrm{MHz}, \mathrm{CDCl}_{3}\right) \delta 9.15$ (d, $J$ $=8.4 \mathrm{~Hz}, 1 \mathrm{H}), 7.96(\mathrm{~d}, J=8.4 \mathrm{~Hz}, 1 \mathrm{H}), 7.81(\mathrm{~d}, J=8.2 \mathrm{~Hz}, 1 \mathrm{H}), 7.62$ $(\mathrm{t}, J=7.5 \mathrm{~Hz}, 1 \mathrm{H}), 7.49(\mathrm{t}, J=7.5 \mathrm{~Hz}, 1 \mathrm{H}), 7.45(\mathrm{~d}, J=8.4 \mathrm{~Hz}, 1 \mathrm{H})$, 3.39 (ddt, $J=11.1,6.9,4.0 \mathrm{~Hz}, 1 \mathrm{H}), 2.98(\mathrm{dd}, J=18.8,7.2 \mathrm{~Hz}, 1 \mathrm{H})$, $2.33(\mathrm{dd}, J=18.8,3.0 \mathrm{~Hz}, 1 \mathrm{H}), 1.38(\mathrm{~d}, J=7.2 \mathrm{~Hz}, 3 \mathrm{H}) ;{ }^{13} \mathrm{C} \mathrm{NMR}$ $\left(100 \mathrm{MHz}, \mathrm{CDCl}_{3}\right) \delta 206.6,162.6,135.6,132.3,129.9,128.9,128.6$, 127.8, 126.3, 123.8, 122.3, 45.7, 32.5, 20.9; HRMS (APCI+) calcd for $\mathrm{C}_{14} \mathrm{H}_{13} \mathrm{O}[\mathrm{M}+\mathrm{H}]^{+}$197.0961, found 197.0963; Chiralpak ID column, $\mathrm{CO}_{2} / \mathrm{CH}_{3} \mathrm{OH} 90: 10,4.0 \mathrm{~mL} / \mathrm{min}, 40{ }^{\circ} \mathrm{C}, 150$ bar, retention times (min) 2.57 (major), 2.77 (minor).

(2S,3S)-2,3-Dimethyl-2,3-dihydro-1H-cyclopenta[a]naphthalen1-one (10) (Mixture of Cis and Trans). A solution of $n-\mathrm{BuLi}(1.6 \mathrm{M}$, $2.1 \mathrm{~mL}, 3.36 \mathrm{mmol})$ was added to a solution of $\mathrm{NH}(i-\operatorname{Pr})_{2}(340 \mathrm{mg}$, $3.36 \mathrm{mmol})$ in THF $(10 \mathrm{~mL})$ at $0{ }^{\circ} \mathrm{C}$, and the solution was stirred for $0.5 \mathrm{~h}$. The solution was cooled to $-78^{\circ} \mathrm{C}$, and a solution of ketone 9 (641 mg, $3.27 \mathrm{mmol})$ in THF $(10 \mathrm{~mL})$ was added dropwise via a syringe. The reaction mixture was stirred for $0.5 \mathrm{~h}$. To the reaction mixture was added $\mathrm{CH}_{3} \mathrm{I}(1.62 \mathrm{~g} 11.41 \mathrm{mmol})$, after which the cooling bath was removed. The reaction mixture was stirred for $16 \mathrm{~h}$ and quenched with a saturated solution of $\mathrm{NH}_{4} \mathrm{Cl}$ (aq) $(20 \mathrm{~mL})$. EtOAc $(50 \mathrm{~mL})$ was added, and the organic layer was washed with a saturated solution of $\mathrm{NaCl}(\mathrm{aq})(3 \times 50 \mathrm{~mL})$, dried over $\mathrm{Na}_{2} \mathrm{SO}_{4}$, and concentrated in vacuo. The crude product was purified by column 
chromatography $\left(\mathrm{SiO}_{2}\right.$, pentane/EtOAc) to afford ketone $(S, S)-10$ (cis/trans 10/90) as a white solid (529 mg, $2.52 \mathrm{mmol}, 77 \%$ yield): ${ }^{1} \mathrm{H}$ NMR $\left(400 \mathrm{MHz}, \mathrm{CDCl}_{3}\right) \delta 9.15(\mathrm{~d}, J=8.4 \mathrm{~Hz}, 1 \mathrm{H}), 8.07(\mathrm{~d}, J=8.4$ $\mathrm{Hz}, 1 \mathrm{H}), 7.89(\mathrm{~d}, J=8.6 \mathrm{~Hz}, 1 \mathrm{H}), 7.76-7.61(\mathrm{~m}, 1 \mathrm{H}), 7.61-7.46(\mathrm{~m}$, $2 \mathrm{H}), 3.60(\mathrm{p}, J=7.4 \mathrm{~Hz}, 1 \mathrm{H})$ (minor), $3.03(\mathrm{qd}, J=7.1,3.7 \mathrm{~Hz}, 1 \mathrm{H})$, $2.94(\mathrm{p}, J=7.3 \mathrm{~Hz}, 1 \mathrm{H})$ (minor), $2.36(\mathrm{qd}, J=7.4,3.9 \mathrm{~Hz}, 1 \mathrm{H}), 1.51$ (dd, $J=7.1,0.7 \mathrm{~Hz}, 3 \mathrm{H}), 1.38(\mathrm{~d}, J=7.4 \mathrm{~Hz}, 3 \mathrm{H}), 1.32-1.27(\mathrm{~m}, 6 \mathrm{H})$ (minor); ${ }^{13} \mathrm{C}$ NMR $\left(101 \mathrm{MHz}, \mathrm{CDCl}_{3}\right) \delta 208.9,160.5,135.8,132.6$, 129.6, 129.3, 128.9, 128.0, 126.5, 124.2, 122.2, 51.7, 41.8, 19.3, 14.7; HRMS (ESI+) calcd for $\mathrm{C}_{15} \mathrm{H}_{15} \mathrm{O}[\mathrm{M}+\mathrm{H}]^{+} 211.1117$ found 211.1118.

(2S,3S)-2-Isopropyl-3-methyl-2,3-dihydro-1H-cyclopenta[a]naphthalen-1-one (11). A solution of $n$-BuLi $(1.6 \mathrm{M}, 2.0 \mathrm{~mL}, 3.23$ $\mathrm{mmol})$ was added to a solution of $\mathrm{NH}(i-\operatorname{Pr})_{2}(327 \mathrm{mg}, 3.23 \mathrm{mmol})$ in THF $(10 \mathrm{~mL})$ at $0{ }^{\circ} \mathrm{C}$, and the solution was stirred for $0.5 \mathrm{~h}$. The solution was cooled to $-78{ }^{\circ} \mathrm{C}$, and a solution of ketone $9(576 \mathrm{mg}$, $2.94 \mathrm{mmol})$ in THF $(10 \mathrm{~mL})$ was added dropwise via a syringe. The solution was stirred for $0.5 \mathrm{~h}$. To the reaction mixture were added HMPA $(527 \mathrm{mg}, 2.94 \mathrm{mmol})$ and $i$-PrI $(1.5 \mathrm{~g} 8.82 \mathrm{mmol})$, after which the mixture was allowed to warm to room temperature. The reaction mixture was stirred for $16 \mathrm{~h}$ and quenched with a saturated solution of $\mathrm{NH}_{4} \mathrm{Cl}$ (aq) $(20 \mathrm{~mL})$. EtOAc $(50 \mathrm{~mL})$ was added, and the organic layer was washed with brine $(3 \times 50 \mathrm{~mL})$, dried over $\mathrm{Na}_{2} \mathrm{SO}_{4}$, and concentrated in vacuo. The crude product was purified by column chromatography $\left(\mathrm{SiO}_{2}\right.$, pentane/EtOAc) to afford ketone 11 as a light yellow oil. (431 mg, $1.81 \mathrm{mmol}, 62 \%$ yield): ${ }^{1} \mathrm{H}$ NMR $(400 \mathrm{MHz}$, $\left.\mathrm{CDCl}_{3}\right) \delta 9.20(\mathrm{~d}, J=8.4 \mathrm{~Hz}, 1 \mathrm{H}), 8.06(\mathrm{~d}, J=8.4 \mathrm{~Hz}, 1 \mathrm{H}), 7.88(\mathrm{~d}, J$ $=8.2 \mathrm{~Hz}, 1 \mathrm{H}), 7.70-7.64(\mathrm{~m}, 1 \mathrm{H}), 7.59-7.51(\mathrm{~m}, 2 \mathrm{H}), 3.28(\mathrm{qd}, J=$ 7.1, $3.0 \mathrm{~Hz}, 1 \mathrm{H}), 2.50(\mathrm{pd}, J=6.9,4.3 \mathrm{~Hz}, 1 \mathrm{H}), 2.33(\mathrm{dd}, J=4.3,3.0$ $\mathrm{Hz}, 1 \mathrm{H}), 1.47(\mathrm{~d}, J=7.1 \mathrm{~Hz}, 3 \mathrm{H}), 1.14(\mathrm{~d}, J=7.0 \mathrm{~Hz}, 3 \mathrm{H}), 0.86(\mathrm{~d}, J$ $=6.8 \mathrm{~Hz}, 3 \mathrm{H}) ;{ }^{13} \mathrm{C}$ NMR $\left(100 \mathrm{MHz}, \mathrm{CDCl}_{3}\right) \delta 208.9,161.9,135.8$, $132.6,130.4,129.1,128.9,128.0,126.5,124.2,122.5,62.1,35.2,29.5$, 21.6, 20.9, 17.9; HRMS (APCI+) calcd for $\mathrm{C}_{17} \mathrm{H}_{19} \mathrm{O}[\mathrm{M}+\mathrm{H}]^{+}$ 239.1430 , found 239.1435 .

2,7-Dibromo-9-((2S,3S)-2,3-dimethyl-2,3-dihydro-1H-cyclopenta[a]naphthalen-1-ylidene)-9H-fluorene (15). A two-neck flask was charged with Lawesson's reagent $(2.31 \mathrm{~g}, 5.71 \mathrm{mmol})$. A solution of 10 (400 mg, $1.90 \mathrm{mmol}, 96 \%$ ee, 90:10 dr) in toluene $(20 \mathrm{~mL}$ ) was added, and the resulting suspension was heated at $100{ }^{\circ} \mathrm{C}$ for $4 \mathrm{~h}$, after which it was cooled to room temperature. The suspension was filtered over a plug of cotton. The filtrate was reduced in vacuo and purified by column chromatography $\left(\mathrm{SiO}_{2}\right.$, pentane $\left./ \mathrm{CH}_{2} \mathrm{Cl}_{2}\right)$. The thioketone was obtained diastereomerically pure in $60 \%$ yield and was added to a solution of 2,7-dibromo-9-diazo-9H-fluorene $(525 \mathrm{mg}, 1.50 \mathrm{mmol})$ in THF $(10 \mathrm{~mL})$. The reaction mixture was stirred for $40 \mathrm{~h}$, subsequently concentrated in vacuo, and purified by column chromatography $\left(\mathrm{SiO}_{2}\right.$, pentane $\left./ \mathrm{CH}_{2} \mathrm{Cl}_{2}\right)$. The obtained mixture of episulfide and alkene was dissolved in THF ( $5 \mathrm{~mL}$ ), treated with tris(dimethylamino)phosphine $(2.00 \mathrm{mmol}, 326 \mathrm{mg})$, and stirred for $16 \mathrm{~h}$ to afford, after purification by column chromatography $\left(\mathrm{SiO}_{2}\right.$, pentane $\left./ \mathrm{CH}_{2} \mathrm{Cl}_{2}\right), 15$ as a yellow solid (401 mg, $0.78 \mathrm{mmol}$, 68\% yield over two steps, $96 \%$ ee). Recrystallization from heptane afforded $\mathbf{1 5}$ enantiomerically pure: $\mathrm{mp}$ $192-195^{\circ} \mathrm{C} ;{ }^{1} \mathrm{H}$ NMR $\left(400 \mathrm{MHz}, \mathrm{CDCl}_{3}\right) \delta 8.07(\mathrm{~d}, J=1.6 \mathrm{~Hz}, 1 \mathrm{H})$, 8.01-7.95 (m, 2H), $7.68(\mathrm{~d}, J=8.1 \mathrm{~Hz}, 1 \mathrm{H}), 7.64-7.61(\mathrm{~m}, 1 \mathrm{H}), 7.59$ $(\mathrm{t}, J=7.8 \mathrm{~Hz}, 2 \mathrm{H}), 7.56-7.50(\mathrm{~m}, 2 \mathrm{H}), 7.43-7.37(\mathrm{~m}, 1 \mathrm{H}), 7.35(\mathrm{dd}$, $J=8.1,1.7 \mathrm{~Hz}, 1 \mathrm{H}), 6.79(\mathrm{~d}, J=1.7 \mathrm{~Hz}, 1 \mathrm{H}), 3.84(\mathrm{q}, J=6.7 \mathrm{~Hz}, 1 \mathrm{H})$, $3.15(\mathrm{q}, J=7.0 \mathrm{~Hz}, 1 \mathrm{H}), 1.44(\mathrm{~d}, J=6.8 \mathrm{~Hz}, 3 \mathrm{H}), 1.38(\mathrm{~d}, J=7.0 \mathrm{~Hz}$, $3 \mathrm{H}) ;{ }^{13} \mathrm{C}$ NMR $\left(100 \mathrm{MHz}, \mathrm{CDCl}_{3}\right) \delta 153.6,153.5,141.4,138.3$, $137.8,137.2,134.2,132.8,132.2,129.7,129.6,129.5,129.3,129.0$, $129.0,127.1,127.0,126.9,125.6,123.2,121.1,120.9,120.1,120.1$, 52.9, 49.5, 21.5, 19.3; HRMS (APCI+) calcd for $\mathrm{C}_{28} \mathrm{H}_{21} \mathrm{Br}_{2}[\mathrm{M}+\mathrm{H}]^{+}$ 516.9984, found 516.9987; Chiracel AD-H column, $n$-heptane/ $i$-PrOH 95:5, $0.5 \mathrm{~mL} / \mathrm{min}, 40{ }^{\circ} \mathrm{C}$, retention times $(\mathrm{min}) 8.00((R, R)-15), 8.95$ $((S, S)-15)$.

2,7-Dibromo-9-((2S,3S)-2-isopropyl-3-methyl-2,3-dihydro- $1 \mathrm{H}$ cyclopenta[a]naphthalen-1ylidene)-9H fluorine (17). A two-neck flask was charged with Lawesson's reagent $(1.272 \mathrm{~g}, 3.15 \mathrm{mmol})$. A solution of $11(250 \mathrm{mg}, 1.05 \mathrm{mmol}, 96 \%$ ee $)$ in toluene $(15 \mathrm{~mL})$ was added, and the resulting suspension was heated at reflux for $3 \mathrm{~h}$. The suspension was filtered over a plug of cotton. The filtrate was reduced in vacuo and purified by column chromatography $\left(\mathrm{SiO}_{2}\right.$, pentane/ $\mathrm{CH}_{2} \mathrm{Cl}_{2}$ ). The obtained thioketone was added to a solution of 2,7dibromo-9-diazo-9H-fluorene $(350 \mathrm{mg}, 1.00 \mathrm{mmol})$ in THF $(10 \mathrm{~mL})$. The reaction mixture was stirred for $40 \mathrm{~h}$, subsequently reduced in vacuo, and purified by column chromatography $\left(\mathrm{SiO}_{2}\right.$, pentane/ $\mathrm{CH}_{2} \mathrm{Cl}_{2}$ ). The obtained mixture of episulfide and alkene was dissolved in THF $(5 \mathrm{~mL})$, treated with tris(dimethylamino)phosphine $(2.00$ $\mathrm{mmol}, 326 \mathrm{mg}$ ), and stirred for $16 \mathrm{~h}$ to afford, after purification by column chromatography $\left(\mathrm{SiO}_{2}\right.$, pentane $\left./ \mathrm{CH}_{2} \mathrm{Cl}_{2}\right), 17$ as a yellow solid (137 mg, $0.25 \mathrm{mmol}$, 24\% yield over three steps, $96 \%$ ee). Recrystallization from heptane afforded 17 with an enantiopurity of 99\% ee: $\mathrm{mp} 118-120{ }^{\circ} \mathrm{C} ;{ }^{1} \mathrm{H}$ NMR $\left(400 \mathrm{MHz}, \mathrm{CDCl}_{3}\right) \delta 8.12$ (d, $J=$ $1.6 \mathrm{~Hz}, 1 \mathrm{H}), 7.99-7.94(\mathrm{~m}, 2 \mathrm{H}), 7.67(\mathrm{~d}, J=8.1 \mathrm{~Hz}, 1 \mathrm{H}), 7.63(\mathrm{~d}, J=$ $8.4 \mathrm{~Hz}, 1 \mathrm{H}), 7.58(\mathrm{~d}, J=8.1 \mathrm{~Hz}, 1 \mathrm{H}), 7.56-7.49(\mathrm{~m}, 3 \mathrm{H}), 7.43-7.37$ (m, $1 \mathrm{H}), 7.35(\mathrm{dd}, J=8.1,1.8 \mathrm{~Hz}, 1 \mathrm{H}), 6.78(\mathrm{~d}, J=1.7 \mathrm{~Hz}, 1 \mathrm{H}), 3.69$ $(\mathrm{d}, J=5.1 \mathrm{~Hz}, 1 \mathrm{H}), 3.35(\mathrm{q}, J=7.0 \mathrm{~Hz}, 1 \mathrm{H}), 2.25(\mathrm{~m}, 1 \mathrm{H}), 1.41(\mathrm{~d}, J$ $=7.0 \mathrm{~Hz}, 3 \mathrm{H}), 1.20(\mathrm{~d}, J=7.0 \mathrm{~Hz}, 3 \mathrm{H}), 0.67(\mathrm{~d}, J=6.7 \mathrm{~Hz}, 3 \mathrm{H}) ;{ }^{13} \mathrm{C}$ NMR $\left(100 \mathrm{MHz}, \mathrm{CDCl}_{3}\right) \delta 154.1,152.7,141.3,138.3,137.9,137.1$, $135.8,132.7,132.1,129.9,129.6,129.5,129.1,129.0,128.7,127.5$, 127.0, 126.9, 125.6, 122.4, 120.8, 120.8, 120.1, 119.9, 63.9, 43.6, 31.5, 21.7, 20.6, 18.9; HRMS (APCI+) calcd for $\mathrm{C}_{30} \mathrm{H}_{25} \mathrm{Br}_{2}[\mathrm{M}+\mathrm{H}]^{+}$ 545.0297, found 545.0301; Chiracel AD-H column, $n$-heptane/ $i$-PrOH 95:5, $0.5 \mathrm{~mL} / \mathrm{min}, 40^{\circ} \mathrm{C}$, retention times $(\min ) 7.29((R, R)-17), 7.88$ $((S, S)-17)$.

9-(2S,3S)-(2,3-Dimethyl-2,3-dihydro-1H-cyclopenta[a]naphthalen-1-ylidene)-9H-fluorene (2). A solution of $n-\mathrm{BuLi}$ in hexanes $(1.6 \mathrm{M}, 0.75 \mathrm{~mL}, 1.2 \mathrm{mmol})$ was added dropwise to a solution of $15(100 \mathrm{mg}, 0.19 \mathrm{mmol})$ in THF $(5 \mathrm{~mL})$ at $-78^{\circ} \mathrm{C}$ via a syringe. The resulting solution was stirred for $15 \mathrm{~min}$, after which $\mathrm{CH}_{3} \mathrm{OH}$ (5 $\mathrm{mL}$ ) was added. The reaction mixture was heated to room temperature, reduced in vacuo, and purified by column chromatography to afford $2\left(55 \mathrm{mg}, 0.15 \mathrm{mmol}, 79 \%\right.$ yield) as a yellow foam: ${ }^{1} \mathrm{H}$ NMR (400 MHz, $\left.\mathrm{CDCl}_{3}\right) \delta 8.01-7.96(\mathrm{~m}, 1 \mathrm{H}), 7.94(\mathrm{dd}, J=8.2,4.3$ $\mathrm{Hz}, 2 \mathrm{H}), 7.90-7.85(\mathrm{~m}, 1 \mathrm{H}), 7.78(\mathrm{dd}, J=8.1,4.1 \mathrm{~Hz}, 2 \mathrm{H}), 7.57$ (d, $J$ $=8.2 \mathrm{~Hz}, 1 \mathrm{H}), 7.51-7.44(\mathrm{~m}, 1 \mathrm{H}), 7.43-7.37(\mathrm{~m}, 2 \mathrm{H}), 7.32(\mathrm{t}, J=7.6$ $\mathrm{Hz}, 1 \mathrm{H}), 7.24(\mathrm{t}, J=7.4 \mathrm{~Hz}, 1 \mathrm{H}), 6.87-6.80(\mathrm{~m}, 1 \mathrm{H}), 6.80-6.74(\mathrm{~m}$, $1 \mathrm{H}), 3.91(\mathrm{q}, J=6.7 \mathrm{~Hz}, 1 \mathrm{H}), 3.11(\mathrm{q}, J=7.0 \mathrm{~Hz}, 1 \mathrm{H}), 1.42(\mathrm{~d}, J=6.7$ $\mathrm{Hz}, 3 \mathrm{H}), 1.37$ (d, $J=7.0 \mathrm{~Hz}, 3 \mathrm{H}) ;{ }^{13} \mathrm{C} \mathrm{NMR}\left(100 \mathrm{MHz}, \mathrm{CDCl}_{3}\right) \delta$ $152.7,150.1,140.1,139.9,139.5,137.1,135.3,132.8,131.9,131.0$, $129.9,128.6,127.6,126.9,126.9,126.8,126.5,125.9,125.8,125.3$, 124.0, 123.3, 119.7, 118.9, 53.1, 49.4, 21.5, 19.3; HRMS (APCI+) calcd for $\mathrm{C}_{28} \mathrm{H}_{23}[\mathrm{M}+\mathrm{H}]^{+} 359.1794$, found 359.1790.

9-((2S,3S)-2-Isopropyl-3-methyl-2,3-dihydro-1H-cyclopenta[a]naphthalen-1-ylidene)-9H-fluorene (3). A solution of $n$-BuLi in hexanes $(1.6 \mathrm{M}, 0.5 \mathrm{~mL}, 0.8 \mathrm{mmol})$ was added dropwise to a solution of $17(80 \mathrm{mg}, 0.15 \mathrm{mmol})$ in THF $(5 \mathrm{~mL})$ at $-78{ }^{\circ} \mathrm{C}$ via a syringe. The resulting solution was stirred for $15 \mathrm{~min}$, after which $\mathrm{CH}_{3} \mathrm{OH}(5$ $\mathrm{mL}$ ) was added. The reaction mixture was heated to room temperature, reduced in vacuo, and purified by column chromatography to afford 3 ( $43 \mathrm{mg}, 0.11 \mathrm{mmol}, 75 \%$ yield) as a yellow foam: ${ }^{1} \mathrm{H}$ NMR $\left(400 \mathrm{MHz}, \mathrm{CDCl}_{3}\right) \delta 8.04-7.98(\mathrm{~m}, 1 \mathrm{H}), 7.97-7.90(\mathrm{~m}, 2 \mathrm{H})$, $7.90-7.85(\mathrm{~m}, 1 \mathrm{H}), 7.81-7.75(\mathrm{~m}, 2 \mathrm{H}), 7.53(\mathrm{~d}, J=8.2 \mathrm{~Hz}, 1 \mathrm{H})$, 7.49-7.44 (m, 1H), 7.44-7.38 (m, 2H), 7.36-7.30 (m, 1H), 7.26$7.20(\mathrm{~m}, 1 \mathrm{H}), 6.83-6.74(\mathrm{~m}, 2 \mathrm{H}), 3.78(\mathrm{~d}, J=5.3 \mathrm{~Hz}, 1 \mathrm{H}), 3.33(\mathrm{q}, J$ $=7.0 \mathrm{~Hz}, 1 \mathrm{H}), 2.33-2.23(\mathrm{~m}, 1 \mathrm{H}), 1.41(\mathrm{~d}, J=7.0 \mathrm{~Hz}, 3 \mathrm{H}), 1.19(\mathrm{~d}, J$ $=7.0 \mathrm{~Hz}, 3 \mathrm{H}), 0.67(\mathrm{~d}, J=6.7 \mathrm{~Hz}, 3 \mathrm{H}) ;{ }^{13} \mathrm{C} \mathrm{NMR}\left(100 \mathrm{MHz}, \mathrm{CDCl}_{3}\right)$ $\delta 153.2,149.4,140.3,139.9,139.4,137.1,136.9,132.6,132.5,130.9$, $129.1,128.7,127.4,126.9,126.8,126.7,126.5,125.9,125.9,125.3$, 124.2, 122.5, 119.6, 118.8, 64.1, 43.6, 31.4, 21.6, 20.7, 19.1; HRMS (APCI+) calcd for $\mathrm{C}_{30} \mathrm{H}_{27}[\mathrm{M}+\mathrm{H}]^{+} 387.2107$, found 387.2110

(士)-(Z)-9-(2,3-Dimethyl-2,3-dihydro-1H-cyclopenta[a]naphthalen-1-ylidene)-2-methoxy-9H-fluorene (18). A two-neck flask was charged with Lawesson's reagent $(2.305 \mathrm{~g}, 5.70 \mathrm{mmol})$. A solution of $( \pm)-10(400 \mathrm{mg}, 1.90 \mathrm{mmol}, 90: 10 \mathrm{dr})$ in toluene $(20 \mathrm{~mL})$ was added, and the resulting suspension was heated at $100{ }^{\circ} \mathrm{C}$ for $4 \mathrm{~h}$. The suspension was filtered over a plug of cotton. The filtrate was reduced in vacuo and purified by column chromatography $\left(\mathrm{SiO}_{2}\right.$, pentane $\left./ \mathrm{CH}_{2} \mathrm{Cl}_{2}\right)$. The thioketone was obtained diastereomerically pure in $60 \%$ yield and was added to a solution of 9-diazo-2-methoxy$9 H$-fluorene $(667 \mathrm{mg}, 3.00 \mathrm{mmol})$ in THF $(10 \mathrm{~mL})$. The reaction 
mixture was stirred for $40 \mathrm{~h}$, subsequently concentrated in vacuo, and purified by column chromatography $\left(\mathrm{SiO}_{2}\right.$, pentane $\left./ \mathrm{CH}_{2} \mathrm{Cl}_{2}\right)$. The obtained mixture of episulfide and alkene was dissolved in THF (10 $\mathrm{mL}$ ), treated with tris(dimethylamino)phosphine $(2.00 \mathrm{mmol}, 326$ $\mathrm{mg}$ ), and stirred for $16 \mathrm{~h}$ to afford after purification by column chromatography $\left(\mathrm{SiO}_{2}\right.$, pentane $\left./ \mathrm{CH}_{2} \mathrm{Cl}_{2}\right) 18(248 \mathrm{mg}, 0.64 \mathrm{mmol}$ $56 \%$ yield over two steps) as a yellow solid (mixture of $E$ and $Z$ isomers). Recrystallization from ethanol afforded (Z)-20: $\mathrm{mp}$ 159-162 ${ }^{\circ} \mathrm{C}$; ${ }^{1} \mathrm{H}$ NMR $\left(400 \mathrm{MHz}, \mathrm{CDCl}_{3}\right) \delta 7.96-7.89(\mathrm{~m}, 3 \mathrm{H}), 7.80(\mathrm{~d}, J=$ $8.4 \mathrm{~Hz}, 1 \mathrm{H}), 7.77-7.72(\mathrm{~m}, 1 \mathrm{H}), 7.63(\mathrm{~d}, J=8.3 \mathrm{~Hz}, 1 \mathrm{H}), 7.57(\mathrm{~d}, J=$ $8.2 \mathrm{~Hz}, 1 \mathrm{H}), 7.49-7.42(\mathrm{~m}, 1 \mathrm{H}), 7.41-7.29(\mathrm{~m}, 3 \mathrm{H}), 6.80(\mathrm{dd}, J=$ $8.3,2.4 \mathrm{~Hz}, 1 \mathrm{H}), 6.32(\mathrm{~d}, J=2.3 \mathrm{~Hz}, 1 \mathrm{H}) 3.90(\mathrm{q}, J=6.8 \mathrm{~Hz}, 1 \mathrm{H})$, $3.11(\mathrm{q}, J=7.0 \mathrm{~Hz}, 1 \mathrm{H}), 2.99(\mathrm{~s}, 3 \mathrm{H}), 1.43(\mathrm{~d}, J=6.7 \mathrm{~Hz}, 3 \mathrm{H}), 1.38$ $(\mathrm{d}, J=7.0 \mathrm{~Hz}, 3 \mathrm{H}) ;{ }^{13} \mathrm{C}$ NMR $\left(100 \mathrm{MHz}, \mathrm{CDCl}_{3}\right) \delta 158.3,152.7$, $150.0,140.3,139.7,138.4,135.1,132.8,132.7,132.0,131.0,129.7$, $128.7,127.9,127.0,126.6,125.7,125.2,123.9,123.4,119.6,118.9$, 115.0, 110.0, 54.4, 52.8, 49.4, 21.4, 19.2; HRMS (ESI+) calcd for $\mathrm{C}_{29} \mathrm{H}_{25} \mathrm{O}[\mathrm{M}+\mathrm{H}]^{+}$389.1900, found 389.1902.

\section{ASSOCIATED CONTENT}

\section{S Supporting Information}

The Supporting Information is available free of charge on the ACS Publications website at DOI: 10.1021/acs.joc.7b00852.

Crystallographic data for compound $\mathbf{1 5}$ (CIF) Analytical data of all title compounds $\left({ }^{1} \mathrm{H}\right.$ NMR, ${ }^{13} \mathrm{C}$ NMR, and HRMS spectra), Eyring plot analysis, UV/vis spectra, CD spectra, crystallographic data, and computational results (PDF)

\section{AUTHOR INFORMATION}

\section{Corresponding Author}

*E-mail: b.l.feringa@rug.nl.

\section{ORCID}

Edwin Otten: 0000-0002-5905-5108

Sander J. Wezenberg: 0000-0001-9192-3393

Ben L. Feringa: 0000-0003-0588-8435

Notes

The authors declare no competing financial interest.

\section{ACKNOWLEDGMENTS}

Financial support from the Ministry of Education, Culture and Science (Gravitation Program 024.001.035), The Netherlands Organization for Scientific Research (NWO-CW, Veni Grant No. 722.014.006 to S.J.W.), European Research Council (Advanced Investigator Grant, No. 694345 to B.L.F.), and NRSC catalysis are gratefully acknowledged.

\section{REFERENCES}

(1) (a) Molecular Switches, 2nd ed; Browne, W. R., Feringa, B. L., Eds; Wiley-VCH: Weinheim, 2011. (b) From Non-Covalent Assemblies to Molecular Machines; Sauvage, J. P., Gaspard, P., Eds; Wiley-VCH: Weinheim, 2010. (c) Molecular Devices and Machines: Concepts and Perspectives for the Nanoworld; Balzani, V., Credi, A., Venturi, M., Eds; Wiley-VCH: Weinheim, 2008. (d) Cheng, C.; Stoddart, J. F. ChemPhysChem 2016, 17, 1780. (e) Erbas-Cakmak, S.; Leigh, D. A.; McTernan, C. T.; Nussbaumer, A. L. Chem. Rev. 2015, 115, 10081. (f) Coskun, A.; Banaszak, M.; Astumian, R. D.; Stoddart, J. F.; Grzybowski. Chem. Soc. Rev. 2012, 41, 19. (g) Kinbara, K.; Aida, T. Chem. Rev. 2005, 105, 1377.

(2) Selected examples: (a) Huang, T. J.; Brough, B.; Ho, C.-M.; Liu, Y.; Flood, A. H.; Bonvallet, P. A.; Tseng, H.-R; Stoddart, J. F.; Baller, M.; Magonov, S. Appl. Phys. Lett. 2004, 85, 5391. (b) Berná, J.; Leigh, D. A.; Lubomska, M.; Mendoza, S. M.; Pérez, E. M.; Rudolf, P.; Teobaldi, G.; Zerbetto, F. Nat. Mater. 2005, 4, 704-710.
(3) Kassem, S.; van Leeuwen, T.; Lubbe, A. S.; Wilson, M. R.; Feringa, B. L.; Leigh, D. A. Chem. Soc. Rev. 2017, DOI: 10.1039/ C7CS00245A.

(4) Selected examples: (a) Li, Q.; Fuks, G.; Moulin, E.; Maaloum, M.; Rawiso, M.; Kulic, I.; Foy, J. T.; Giuseppone, N. Nat. Nanotechnol. 2015, 10, 161. (b) Foy, J.; Li, Q.; Goujon, A.; Colard-Itté, J.-R.; Fuks, G.; Moulin, E.; Schiffmann, O.; Dattler, D.; Funeriu, D.; Giuseppone, N. Nat. Nanotechnol. 2017, DOI: 10.1038/nnano.2017.28.

(5) Neubauer, T. M.; van Leeuwen, T.; Zhao, D.; Lubbe, A. S.; Kistemaker, J. C. M.; Feringa, B. L. Org. Lett. 2014, 16, 4220.

(6) Pijper, T. C.; Pijper, D.; Pollard, M. M.; Dumur, F.; Davey, S. G.; Meetsma, A.; Feringa, B. L. J. Org. Chem. 2010, 75, 825.

(7) Liu, H.; El-Salfiti, M.; Chai, D. I.; Auffret, J.; Lautens, M. Org. Lett. 2012, 14, 3648.

(8) Liu, H.; El-Salfiti, M.; Lautens, M. Angew. Chem., Int. Ed. 2012, 51, 9846.

(9) Gericke, K. M.; Chai, D. I.; Bieler, N.; Lautens, M. Angew. Chem., Int. Ed. 2009, 48, 1447.

(10) Tietze, L. F.; Waldecker, B.; Ganapathy, D.; Eichhorst, C.; Lenzer, T.; Oum, K.; Reichmann, S. O.; Stalke, D. Angew. Chem., Int. Ed. 2015, 54, 10317.

(11) Tietze, L. F.; Düfert, M. A.; Hungerland, T.; Oum, K.; Lenzer, T. Chem. - Eur. J. 2011, 17, 8452.

(12) Tietze, L. F.; Hungerland, T.; Eichhorst, C.; Düfert, A.; Maaß, C.; Stalke, D. Angew. Chem., Int. Ed. 2013, 52, 3668.

(13) Tietze, L. F.; Düfert, A.; Lotz, F.; Sölter, L.; Oum, K.; Lenzer, K.; Beck, T.; Herbst-Irmer, R. J. Am. Chem. Soc. 2009, 131, 17879.

(14) Tietze, L. F.; Hungerland, T.; Depken, C.; Maaß, C.; Stalke, D. Synlett 2012, 23, 2516.

(15) Tietze, L. F.; Hungerland, T.; Düfert, A.; Objartel, I.; Stalke, D. Chem. - Eur. J. 2012, 18, 3286.

(16) van Delden, R. A.; ter Wiel, M. K. J.; de Jong, H.; Meetsma, A.; Feringa, B. L. Org. Biomol. Chem. 2004, 2, 1531.

(17) Kistemaker, J. C. M.; Pizzolato, S. F.; van Leeuwen, T.; Pijper, T. C.; Feringa, B. L. Chem. - Eur. J. 2016, 22, 13478.

(18) Hillier, M. C.; Desrosiers, J. N.; Marcoux, J. F.; Grabowski, E. J. J. Org. Lett. 2004, 6, 573.

(19) Frisch, M. J.; Trucks, G. W.; Schlegel, H. B.; Scuseria, G. E.; Robb, M. A.; Cheeseman, J. R.; Scalmani, G.; Barone, V.; Mennucci, B.; Petersson, G. A.; Nakatsuji, H.; Caricato, M.; Li, X.; Hratchian, H. P.; Izmaylov, A. F.; Bloino, J.; Zheng, G.; Sonnenberg, J. L.; Hada, M.; Ehara, M.; Toyota, K.; Fukuda, R.; Hasegawa, J.; Ishida, M.; Nakajima, T.; Honda, Y.; Kitao, O.; Nakai, H.; Vreven, T.; Montgomery, J. A., Jr.; Peralta, J. E.; Ogliaro, F.; Bearpark, M.; Heyd, J. J.; Brothers, E.; Kudin, K. N.; Staroverov, V. N.; Kobayashi, R.; Normand, J.; Raghavachari, K.; Rendell, A.; Burant, J. C.; Iyengar, S. S.; Tomasi, J.; Cossi, M.; Rega, N.; Millam, N. J.; Klene, M.; Knox, J. E.; Cross, J. B.; Bakken, V.; Adamo, C.; Jaramillo, J.; Gomperts, R.; Stratmann, R. E.; Yazyev, O.; Austin, A. J.; Cammi, R.; Pomelli, C.; Ochterski, J. W.; Martin, R. L.; Morokuma, K.; Zakrzewski, V. G.; Voth, G. A.; Salvador, P.; Dannenberg, J. J.; Dapprich, S.; Daniels, A. D.; Farkas, Ö.; Foresman, J. B.; Ortiz, J. V.; Cioslowski, J.; Fox, D. J. Gaussian 09, revision D.01; Gaussian: Wallingford, CT, 2013.

(20) Becke, A. D. J. J. Chem. Phys. 1993, 98, 5648.

(21) Vosko, S. H.; Wilk, L.; Nusair, M. Can. J. Phys. 1980, 58, 1200.

(22) Lee, C.; Yang, W.; Parr, R. G. Phys. Rev. B: Condens. Matter Mater. Phys. 1988, 37, 785. 